\title{
OCCURRENCE OF TETRANYCHUS URTICAE KOCH AND ITS MAIN MITE PREDATORS ON LUPIN AT EL- KHATARA DISTRICT, SHARKIA GOVERNORATE, EGYPT (TETRANYCHIDAE \& PHYTOSEIIDAE)
}

\author{
O. M.O. Mohamed ${ }^{1}$ and Omar, N.A.A. ${ }^{2}$ \\ 1- Plant Protection Research Institute, A.R.C., Dokki, Egypt. \\ 2- Institute of Efficient Productivity, Zagazig University, Zagazig, Egypt.
}

\begin{abstract}
The present work was carried out to study the population fluctuation of mites inhabiting lupin, Lupinus termes L. at El- Khatara district, Sharkeia Governorate, Egypt, during the two successive growing seasons of 2004/ 05 and 2005/06. The recorded phytophagous species was the two spotted spider mite, Tetranychus urticae Koch (Fam. Tetranychidae) and its natural enemies, Amblyseius swirskii Athias - Henriot and A. cydnodactylon Shehata \& Zaher (Fam. Phytoseiidae). The highest values of population density for T. urticae and its predatory species were recorded at the times of high temperature and low relative humidity through the end of the two seasons.
\end{abstract}

Key words: Population fluctuation, Tetranychus, Phytoseiidae, lupin.

\section{INTRODUCTION}

Lupin, Lupinus termes L. as a legume crop is recognized as one of the oldest crops for about 4000 years (Ibrahim, 1990). Its importance to many of the Mediterranean civilizations was apparently independently domesticated in both the old and new world (Gross, 1986 and Holden et al., 2005). In Egyp, 3745 feddans were cultivated with lupin during season of 2007. Field observation showed that lupin is liable to be attacked by several mite species causing damage to the plants .

Thus, the present authours thought to study the mites inhabiting that crop, especially their is no previous data dealing with such study.

The present work aimed to study the occurrence of the serious phytophagous mite, $T$. urticae on lupin crop in addition to its predators during the two growing seasons 2004/05 \& 2005 /06 at El- Khatara district, Sharkia Governorate, Egypt.

\section{MATERIALS AND METHODS}

\section{1- Experimental design:}

An experiment was carried out at El -Khatara district, Sharkia Governorate, during the two successive growing lupin seasons of 2004 / 05 and 2005 / 06 to study the population fluctuation of Tetranychus urticae Koch and its mite natural enemies, Amblyseius swirskii Athias-Henriot and A. cydnodactylon Shehata \& Zaher. The experimental area was chosen and divided into three plots, each plot equals $1 / 8$ feddan $\left(21 \times 25 \mathrm{~m}^{2}\right)$. It was characterized by sandy soil and was the previous crop. The border 
width was $60 \mathrm{~cm}$ between plots . The field was planted with Lupinus termes L. on November, $15^{\text {th }}$ during both seasons. Normal agricultural practices were followed and no pesticidal treatments were applied during the whole experimental period.

\section{2- Population fluctuation of mites:}

Samples were randomly collected from diagonals of the inner square area of each experiment plot. For counting the mite species, 50 leaves were sampled fortnight intervals from each plot through different levels of the plant. The upper and lower surfaces of the leaf were examined carefully (Hassanein et al., 1971).

The obtained data were statistically analyzed according to Snedcor and Chochran (1980) to show the influence of temperature and relative humidity on population density of the mite species. The. difference between means were tested using Duncan s New Multiple Range Test (Duncan, 1955).

\section{RESULTS AND DISCUSSION}

Data presented in Tables (1\&2) and Figure 1 (A-D) show the population behaviour of the two spotted spider mite, Tetranychus urticae Koch and its mite natural enemies, Amblyseius swirskii Athias- Henriot and A. cydnodactylon Shehata \& Zaher associated with lupin plants from December to April during the two growing seasons of 2004/ $05 \& 2005 / 06$.

\section{1- Population fluctuation of Tetranychus urticae:}

This phytophagous mite started its infestation from Jan. $1^{\text {st }}, 2005$ with 6 mites/ leaf, at $16.3^{\circ} \mathrm{C}$ and $64.9 \%$ R.H. . The mean density increased gradually showing one peak at the first half of April with a mean number of 82 mites/ leaf, at $20.3^{\circ} \mathrm{C}$ and $57.9 \%$ R.H. , then decreased again to 80 mites/ leaf when the plants begun to dryness at $23.4^{\circ} \mathrm{C}$ and $55.5 \%$ R.H., (table , 1 and fig., $1 \mathrm{~A} \& \mathrm{~B}$ ).

In the second season 2005/ 06 the infestation started at 15 December 2005 with 7 mites/ leaf at $17.1^{\circ} \mathrm{C}$ and $65.1 \%$ R.H. until the last half of April making two peaks at $15^{\text {th }}$ Jan. and $15^{\text {th }}$ Feb., with a mean numbers of 21 and 38 mites/ leaf at $15.6,17.6$ and 64.4, 63.6\% R.H., respectively ( Table 2 and Figure 1, A \& B).

\section{2- Population fluctuation of natural enemies of $\boldsymbol{T}$. urticae:}

A-Amblyseius swirskii:

During the first season, 2004/ 05, the predator appeared for the first time in $15^{\text {th }}$ Jan.2005 with a mean number of about 6 individuals/ leaf at $17.3^{\circ} \mathrm{C}$ and $59.4 \%$ R.H., and the population increased gradually reaching a mean number of about 20 individuals/ leaf at $1^{\text {st }}$ March, showing its peak, at $18.9^{\circ} \mathrm{C} \& 60.8 \%$ R.H. . Then the mean density declined, reaching 6 individuals/ leaf in $15 \mathrm{March}$, at $18.2^{\circ} \mathrm{C} \& 60.3 \%$ R.H. Afterwards, the population increased until the end of the growing season recording 23 individuals/ leaf in $15^{\text {th }}$ April, at $23.4^{\circ} \mathrm{C} \& 55.5 \%$ R.H.( Table 1 and Figure1, A \& C). During the second season, 2005/06, the predator recorded two peaks in $15 \mathrm{Jan}$. and $15 \mathrm{Feb}$. recording $10 \& 19$ individuals/ leaf, at $15.6 \& 17.6^{\circ} \mathrm{C}$ and 64.4 
Table 1: Mean numbers of Tetranychus urticae Koch and its predators Amblyseius swirskii Athias-Henriot and A. cydnodactylon Shehata \& Zaher per leaf of lupin at El-Khatara, Sharkia Governorate during 2004/05.

\begin{tabular}{|c|c|c|c|c|c|c|}
\hline \multicolumn{2}{|c|}{ Inspects } & $\begin{array}{l}\text { Tetranychus } \\
\text { urticae }\end{array}$ & $\begin{array}{l}\text { Amblyseius } \\
\text { swirskii }\end{array}$ & Amblyseius & Temp. & R.H. \% \\
\hline \multirow{2}{*}{ December } & 1 & 0 & 0 & 0 & 19.2 & 68.9 \\
\hline & 15 & 0 & 0 & 0 & 18.3 & 63.6 \\
\hline \multirow{2}{*}{ January } & 1 & 6 & 0 & 3 & 16.3 & 64.9 \\
\hline & 15 & 12 & 6 & 0 & 17.3 & 59.4 \\
\hline \multirow{2}{*}{ February } & 1 & 26 & 11 & 6 & 13.7 & 61.0 \\
\hline & 15 & 44 & 13 & 10 & 18.9 & 68.9 \\
\hline \multirow{2}{*}{ March } & 1 & 57 & 20 & 13 & 18.9 & 60.8 \\
\hline & 15 & 61 & 6 & 17 & 18.2 & 60.3 \\
\hline \multirow{2}{*}{ April } & 1 & 82 & 16 & 21 & 20.3 & 57.9 \\
\hline & 15 & 80 & 23 & 25 & 23.4 & 55.5 \\
\hline
\end{tabular}

Table 2: Mean numbers of Tetranychus urticae Koch and its predators Amblyseius swirskii Athias-Henriot and A. cydnodactylon Shehata \& Zaher per leaf of lupin at El-Khatara, Sharkia Governorate during 2005/06.

\begin{tabular}{llllllll}
\hline \multicolumn{1}{rl}{ Inspects } & $\begin{array}{l}\text { Tetranychus } \\
\text { urticae }\end{array}$ & $\begin{array}{l}\text { Amblyseius } \\
\text { swirskii }\end{array}$ & $\begin{array}{l}\text { Amblyseius } \\
\text { cydnodactylon }\end{array}$ & $\begin{array}{l}\text { Temp. } \\
{ }^{\circ} \mathbf{C}\end{array}$ & $\begin{array}{l}\text { R.H. } \\
\%\end{array}$ \\
\hline \multirow{2}{*}{ December } & $\mathbf{1}$ & 0 & 0 & 0 & 19.4 & 69.8 \\
& $\mathbf{1 5}$ & 7 & 0 & 0 & 17.1 & 65.1 \\
\hline \multirow{2}{*}{ January } & $\mathbf{1}$ & 11 & 0 & 0 & 14.8 & 65.4 \\
& $\mathbf{1 5}$ & 21 & 10 & 5 & 15.6 & 64.4 \\
\hline \multirow{2}{*}{ February } & $\mathbf{1}$ & 19 & 7 & 9 & 16.3 & 62.8 \\
& $\mathbf{1 5}$ & 38 & 19 & 4 & 17.6 & 63.6 \\
\hline \multirow{2}{*}{ March } & $\mathbf{1}$ & 32 & 14 & 6 & 18.8 & 61.9 \\
& $\mathbf{1 5}$ & $\mathbf{7 0}$ & 18 & 12 & 20.2 & 59.8 \\
\hline \multirow{2}{*}{ April } & $\mathbf{1}$ & 95 & 24 & 7 & 21.4 & 59.4 \\
& $\mathbf{1 5}$ & 103 & 30 & 26 & 23.9 & 57.5 \\
\hline
\end{tabular}

\& $63.6 \%$ R.H., respectively. Afterwards, the mean density decreased recording 14 individuals/ leaf, at $1^{\text {st }}$ March. Then the population increased until the end of the growing season with 30 individuals/ leaf, at $23.9^{\circ} \mathrm{C}$ and $57.5 \%$ R.H.( Table 2 and Figure1, A \& C). 

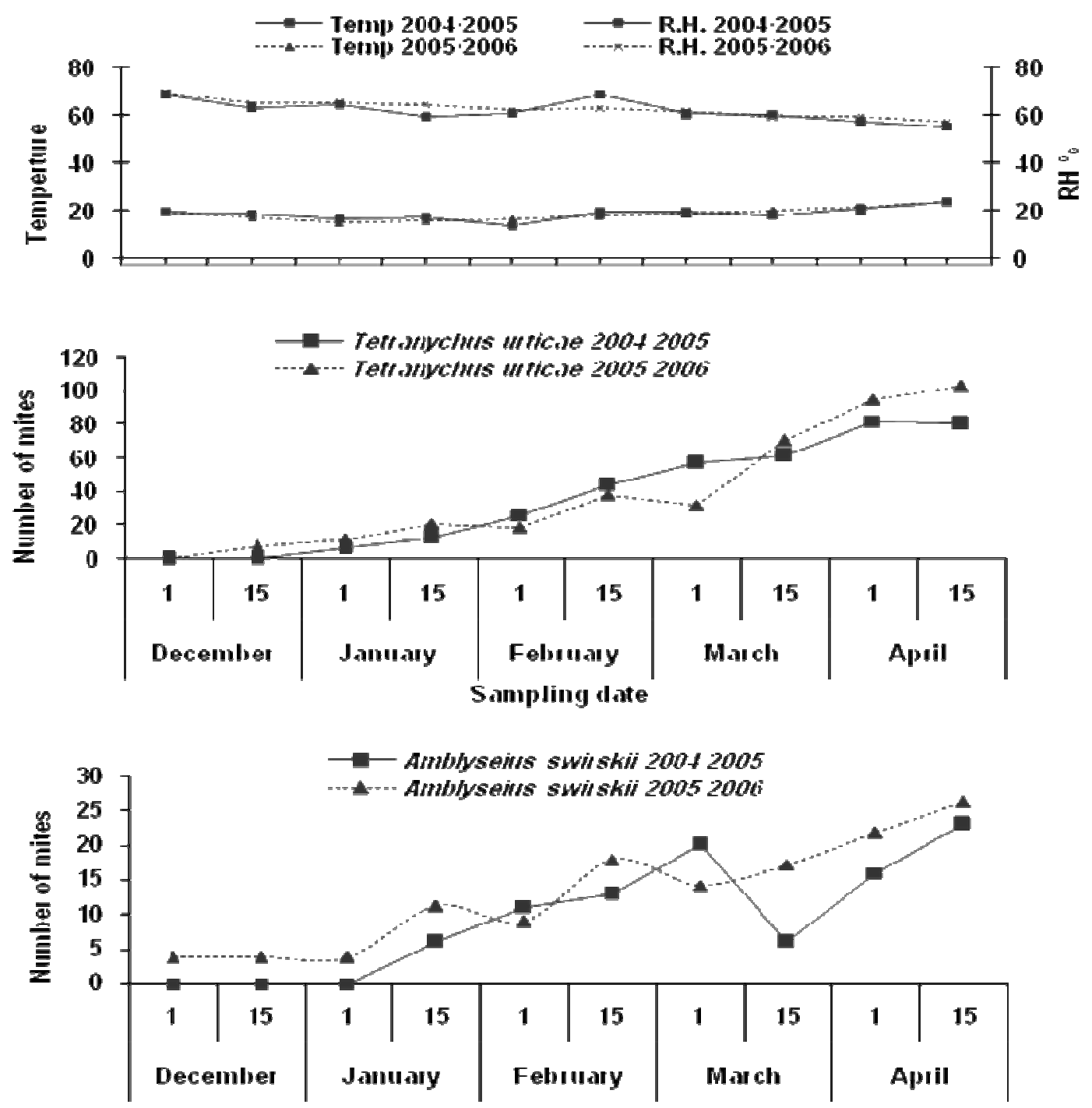

Sampling date

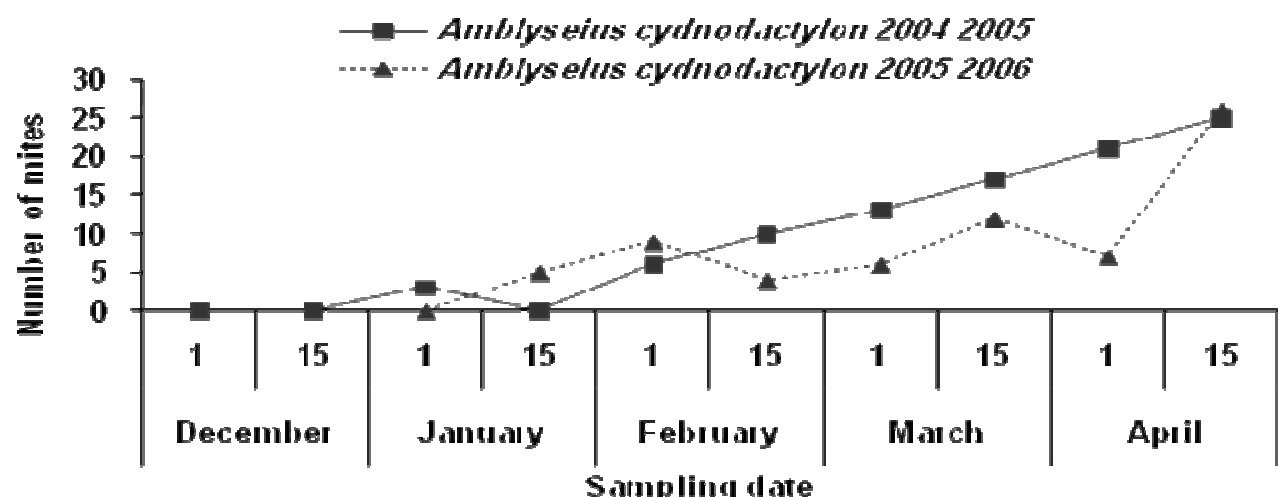

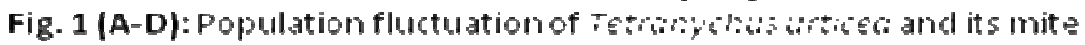

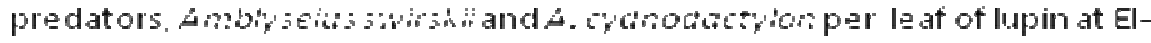
Khat at sharkid Govemorate during 200405 and 2005.06 seasons. 
b- Amblyseius. cydnodactylon:

During the first season, 2004/05, the predator appeared for the first time in $1^{\text {st }}$ Jan. 2005 and increased reaching its peak, with a mean number of about 3 individuals/ leaf, at $16.3^{\circ} \mathrm{C}$ and $64.9 \%$ R.H.. Then it dropped to zero in $15^{\text {th }} \mathrm{Jan}$.

Afterwards, the population increased gradually reaching the maximum value, 25 individuals/ leaf in $15^{\text {th }}$ April, at $23.4^{\circ} \mathrm{C}$ and $55.5 \%$ R.H.( Table 1 and Fig. 1 ,A \& D). In the second season, 2005/ 06 it was recorded at Jan. $15^{\text {th }}$ until the second half of April, showing two peaks. The first peak at Feb. $1^{\text {st }}$ and the second at March $15^{\text {th }}$, with a mean number of about $9 \& 12$ individuals/ leaf, at $16.3 \& 20.2^{\circ} \mathrm{C}$ and $62.8 \& 55.8 \%$ R.H., respectively. The maximum value was recorded at the end of the season with 26 individuals/ leaf, at $23.9^{\circ} \mathrm{C}$ and $57.5 \%$ R.H.( Table 2 and Figure 1, A \& D).

The previous results indicate that the population density for T. urticae and its mite predators were increased with high temperature and low relative humidity. These results coincided with those obtained by Mohamed (2004), who studied the population fluctuation of Tetranychus cucurbitacearum (Sayed) infesting lupin in ElSalheia district during 1999- 2001, and showed that its population increased reaching the maximum values at the end of the two seasons. Farag et al. (1998) recorded that the phytophagous and its predaceous mites on leguminous vegetables in Kaliobia and Giza Governorate throughout one year. They found that, the tetranychid mite, Tetranychus urticae was the most dominant phytophagous species found on the the crop. On kidney-been, Phaseolus vulgaris the highest infestation was recorded in September and November (88 and 114 individuals/leaf, respectively. Also, the population fluctuation of Tetranychus urticae and three phytoseiid predators were studied under greenhouse and field on kidney been (Phaseolus vulgaris) by (YoungIn et al., 1998). They showed that the mite, T. urticae and its predatory mites were found throughout the period of the study. Amir and Kandeel (1988) studid that the incidence of insects and mites associated with lentil plants as a legume crop at Zagazig district, Sharkia Governorate during the two seasons 1984- 1986. They studied the population density and seasonal fluctuation of insect pests. Biasi and Santos (1988) determined the susceptibility of white lupin, Lupinus albus L. as a green manure to Tetranychus ludeni Zacher in artificial infested fields in Parana, Brazil, in 1988.

Conclusively, plants were infested between 80 and 100 days after planting and the evaluation was carried out 140 days after planting. It is concluded that lupin plant is susceptible to the mite.

\section{REFERENCES}

Amir, M. M. I. and Kandeel, M. M. H. (1988): Preliminary survey of insects and mites inhabiting lentil plants at Zagazig district, Sharkia Governorate, Egypt. Zagazig J. Aric. Res.,15(2): 872-885. 
Biasi , L. and Santos, H. (1988): Susceptibility of vetch (Vicia sativa L.) and white lupin (Lupinus albus L.) to the phytophagous mites, Tetranychus ludeni Zacher (Acari: Tetranychidae). Revista-do-Setor-do-Ciencias-Agrarias, 10 (1-2): 179-182.

Duncan,D. B. (1955): Multiple Range \& Mutiple F. Test. Biometrics, 11: 1-42.

Farag, A. M. I.; Magada, K. M. and Nadia, H. H. (1998): Survey of mites inhabiting Cucurbitaceous and Leguminous vegetables in Kaliobia and Giza Governorates. J. Agric. Res., 76 (1): 63-68.

Gross, R. (1986): Lupin the old and now world, biological cultural co- evolution, p. 244- 277. In: Proceeding Fourth International Lupin Conf.,Aug. 15- 22, Geraldton W., Australia

Hassanein, M. H.:Sobae, A. H.: Khalil, F. M. and Mouftah, E. A. (1971): Studied on Aphis gossypii and A. craccivora in cotton field of upper Egypt (Hemiptera: Aphididae). Bull. Soc. ent.. Egypte, 55: 163- 169.

Holden, L.; Faeste, C.K. and Egaas, E. (2005). Quantitative sandwich ELISA for the determination of lupin (Lupinus spp.)in foods. J. Agric. Food Chem., 53: 5866- 5871.

Ibrahim, A. I. M. (1990): Effect of some agronomic pratices on growth and yield of lupin (lupins termis, L.) .Ph. D. Thesis, Fac. Agric., Zagazig Univ.,p.195.

Mohamed, O. M. O. (2004): Ecological and biological studies on some mites associated with field crops in new reclaimed areas at Sharkeia Governorate. Ph. D. Thesis, Fac. Agric., Al- Azhar Univ., p. 241.

Snedecor, G. W. and Chochran, W. G (1980): Statistical Methods. $7^{\text {th }}$ Edition. Iowa State University, Press, USA: pp. 365- 372.

YoungIn, L.; Kwon, GM.; Lee, SW.; Ryu, HK. and Ryu, OH. (1998): Density fluctuation of Tetranychus urticae and three predatory mite species (Phytoseiidae) by the differently infested levels. J. Appl. Entomol., 36 (3): 237- 24. 


\section{تواجد العنكبوت الأحمر ذو البقعتين ومفترساته الرئيسية علي نبات الترمس في منطقة الخطارة بمحافظة الثرقية الأينة}

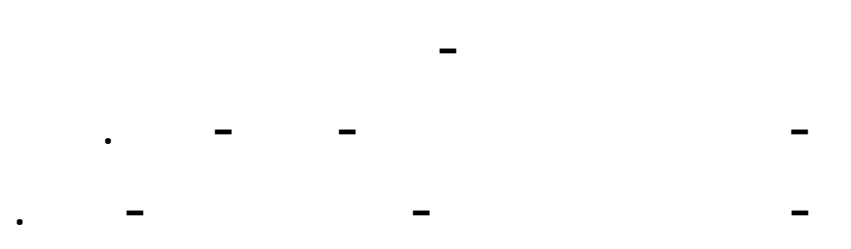

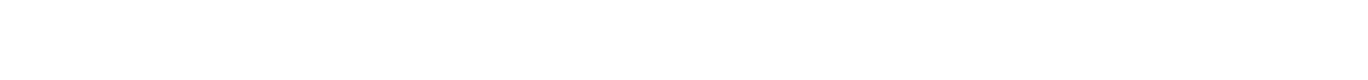

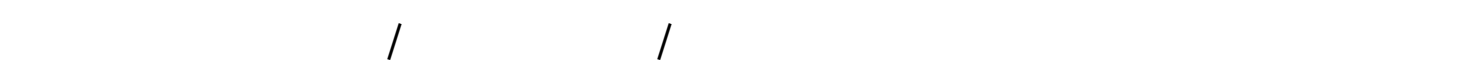

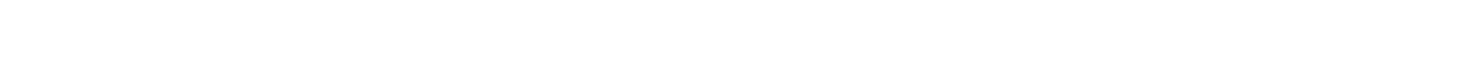
Amblyseius وأهه أعدائه الحيوية من الأكاروسك وهي النوين Tetranychus urticae A. swirskii, cydnodactylon

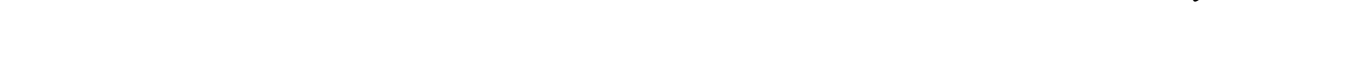
درجلت الحرارة العالية والرطوبة المنخفضة خلال موسمي الدرلسة. 